\title{
Evaluation of Business Intelligence Projects Success - a Case Study
}

\author{
Ana Teixeira \\ NOVA Information Management School, Tintas Robbialac, Lisboa, Portugal \\ Tiago Oliveira \\ NOVA Information Management School, Lisboa, Portugal \\ João Varajão \\ University of Minho, Centro ALGORITMI, Braga, Portugal
}

\section{Abstract}

Background: Many studies found in literature only focus on specific aspects of the evaluation of the success of projects, such as the criteria for evaluation; and just a few are focused on the activities for evaluating success. Objectives: The goal of the paper is to present the process for evaluating the success of Business Intelligence (BI) projects in a large company. Methods/Approach: An exploratory case study was carried out at Tintas Robbialac, SA, a Portuguese company of the paint industry. Results: The specific company approach for evaluating the success of $\mathrm{Bl}$ projects is presented and discussed. Conclusions: The process for evaluating the success of $\mathrm{Bl}$, as well as the evaluation criteria, should be formally defined; and the success should be evaluated and monitored along all the project lifecycle.

Keywords: Business Intelligence, project success, success evaluation, case study JEL Classification: M15

Paper type: Research article

Received: May 29, 2018

Accepted: Jan 03, 2019

Citation: Texiera, A., Oliveira, T., Varajão, J. (2019), "Evaluation of Business Intelligence Projects Success - a Case Study", Business Systems Research, Vol. 10, No. 1, pp. 1-12. DOI: 10.2478/bsrj-2019-0001

Acknowledgments: This paper is an extension of the MSc thesis of author Ana Teixeira.

\section{Introduction}

Recently organizations began to have more consideration for Business Intelligence (BI), once it helps to get competitive advantages (Dobrev et al., 2015; Ivan, 2014; Schlegelmilch et al., 2014; Thamir et al., 2015).

Several studies have shown the importance of $\mathrm{BI}$ in decision-making in the company (Istrat et al., 2015). According to Thamir et al. (2015), BI provides managers and their teams with new tools to enhance the processing of data, and thus decisionmaking becomes more effective.

The success of BI projects needs to be evaluated, taking into account its relevance. Todorović et al. (2015) presented a model to study the way the analysis of the project success enhances the development of the project, and results confirmed that there is a significant correlation. Furthermore, Varajão (2016) proposes "success 
management" as a new knowledge area of project management, and Varajão (2018) presents a process for managing success.

This work explores the theme of success evaluation in BI Projects, following Varajão and Trigo (2016) case study structure, aiming to fill a gap in the BI literature. In this way, four Research Questions (RQs) were defined, as introduced in Teixeira et al. (2018):

- RQ1 - When should the evaluation of a BI project be done?

- RQ2 - Who should participate in the evaluation of a BI project?

- RQ3 - How should the evaluation of a BI project be done?

- RQ4 - Which criteria should be used for evaluating a BI project?

Aiming to get answers to these questions, this research presents a case study carried out in the company Tintas Robbialac, SA.

This paper is organized as follows. Next section summarizes the literature on $\mathrm{BI}, \mathrm{BI}$ Projects, and evaluation of projects success. The research method is described in section three, followed by results and the discussion sections (sections four and five). Finally, the conclusion is presented in section six.

\section{Theoretical Background}

According to Westfall (2012, pp. 64-65), an Information System (IS) can be defined as a "set of interrelated components that collect (or retrieve), process, store, and distribute information to support decision making and control in an organization." $\mathrm{BI}$ is an important area of IS due to the potential to analyze and solve problems of the company (Fourati-Jamoussi et al., 2016). These concepts are well present in the literature (Besteiro et al., 2015; de Carvalho et al., 2015; Gable et al., 2008; Petter et al., 2012; Todorović et al., 2015).

\section{Business Intelligence}

We can find different definitions for $\mathrm{BI}$ in the research literature.

According to Thamir et al. (2015, pp. 34), "BI is an umbrella that includes architecture, tools, applications, databases, and methodologies; (...) to improve performance and to establish competitive advantages".

Tavallaei et al. (2015) also mentioned that BI allows for making strategic decisionmaking. Grenci (2015) states that it involves various levels of analysis and decision support (from predictive analysis to standard reporting).

More recently, Pejić-Bach et al. (2018) have defined $\mathrm{Bl}$ as an approach that includes processes and systems for transformation of the raw data into meaningful and useful information which enables effective, systematic and purposeful analysis of an organization and its competitive environment.

According to Khan et al. (2012, pp. 21), "the objective of $\mathrm{BI}$ is to improve the timeliness and quality of information, and enable managers to be able to better understand the position of their firm as in comparison to competitors." Thamir et al. (2015) add that the manipulation and appropriate analyses of these data by business managers are also the main objectives of BI. In other words, BI transforms the data into useful information and helps business users in decision-making with real-time data (Obeidat et al., 2015).

Many studies discuss the importance of $\mathrm{Bl}$ in organizations, such as:

- Rusaneanu (2013) approaches the benefits and the performance of $\mathrm{Bl}$ software;

- Tomasura (2015) also presents a similar point regarding the importance of BI models in a company; 
- Chaudhuri et al. (2011) and Nyblom et al. (2012) approach the importance of BI Systems in decision support;

- Schlesinger et al. (2015) also study the importance of BI tools in decision support;

- Ivan (2014) presents the competitive advantages of having BI software or $\mathrm{BI}$ tools, as well as, the importance of obtaining data in real time to help in decision making;

- Schlegelmilch et al. (2014) presented similar points to Ivan (2014);

- Morio (2014) approaches the importance of BI to obtain data in real time and to transform data into useful information;

- Evans (2015) approaches the importance of $\mathrm{BI}$ in modern analytics and the relation among $\mathrm{IS}, \mathrm{BI}$, statistics and quantitative methods.

Business Intelligence Systems (BIS) refer to a "wide range of technologies and applications useful for retrieving and analyzing a large amount of information with the goal to generate knowledge useful for making an effective business decision" (PejićBach et al., 2017). BIS initiatives are usually driven by improving marketing and sales (Bosilj Vukšić et al., 2013). To note the importance of knowledge formalization (Ardimento et al., 2013) and knowledge management (Greco, 2013) in this context. Knowledge management not only helps to maximize the internal efficiency of the organization, as well as promotes competitive advantage (Terzieva et al., 2016).

\section{Business Intelligence projects}

According to Rechenthin (2013), a project is a temporary effort to create a product, service or other results. Besteiro et al. (2015) add that projects consist of a complex set of processes. The effectiveness of an organization is partly dependent on the success of its projects (Nenni et al., 2014).

A BI project can be defined as a set of activities that, after being concluded, can help in decision-making. A Bl project can also help to solve different gaps in the company. A BI project depends on the ability of the project team to design, solve problems, understand ideas, learn, and to succeed (Rechenthin, 2013).

Project Management (PM) "is a discipline that applies knowledge and tools in the elaboration of activities associated (projects) to reach an objective or a range of predefined objectives" (Pelegrini et al., 2015, pp. 281). Varajão (2016, pp. 1096) adds that "PM is essential for the development of successful projects, being transversal and having applications in many industries," stating that PM increases efficiency, effectiveness, and project success.

\section{Evaluation of project success}

Many authors consider success as a synonymous of efficiency (project management performance) and effectiveness (Ika, 2009; Serra et al., 2015).

In the literature, project success is defined in different ways. According to Khang et al. (2008, pp. 73), it is defined through three dimensions: "the efficiency of the implementation process, the perceived quality of the project and the client's satisfaction." In 2004, Collins et al. (2004), concluded that "project success consists of two components: product success and project management success." Later, Besteiro et al. (2015) state that for the success of the project it is important to have into account project success factors and success criteria. Gemünden (2015, pp.5) defined project success differently, "as meeting wider business and enterprise goals as defined by key stakeholders." Varajão (2016, pp. 1096) also presented a project success definition, by citing Collins et al. (2004): "there are two distinct components of project success: project management success; and the success of deliverables of the project." 
According to Ika (2009), project success criteria refers to a group of principles used to determine project success. Besteiro et al. (2015) and Varajão (2016) add that this concept should be related to metrics to allow determining the success or failure of the project.

The conclusion is that the major studies are related, for instance, with success factors or project management success (Varajão, 2016). However, questions about "who," "when" and "how" the evaluation of project success should be done, are not well answered yet (Varajão, 2016; Varajão, 2018; Varajão et al., 2018), particularly in what concerns to BI projects.

\section{Method}

With the purpose of describing the evaluation of $\mathrm{Bl}$ projects success, an exploratory case study was carried out at the company Tintas Robbialac, SA. This research complies with the criteria of relevance, applicability, and specificity, as proposed by Cheng et al. (1983) in their work about integrating organization research and practice (Loebbecke et al., 2016; Varajão et al., 2016).

Tintas Robbialac, SA is a paint industry company that belongs to an international group with branches in nine countries (one in America, one in Africa, one in Asia, and six in Europe). Customers are mainly from construction companies and independent distribution. Founded in 1931, Tintas Robbialac, SA develops its activity in four business areas: decorative paints; thermal insulation; protection and maintenance; and vehicle refinishing. In this company, $\mathrm{BI}$ projects are developed by the $\mathrm{BI}$ department (which is part of the commercial area). This department interacts with the main areas in the company: Marketing; Production (logistics); Financial; and Commercial. Tintas Robbialac, SA was selected for this case study because it is pointed as a good reference of $\mathrm{BI}$ projects practices in its business sector, and the last few years $\mathrm{BI}$ has gained a great relevance within the business group.

The data gathering was conducted through eleven interviews that took place in June and July of 2016. During the interviews, the participants were asked about their background information and to give an overview of the $\mathrm{Bl}$ department and $\mathrm{Bl}$ projects. After this, the interviews focused on the process of evaluating BI projects success. The script used in the interviews is presented in the appendix.

The interviews were held informally face-to-face, being on average 30 minutes long. The participants were from different departments and different organizational hierarchy levels, aiming at obtaining different views about the subject. To assure anonymity, the names of participants are mentioned using the format "INTX" (the X identifies the number of the interviewee).

The adopted informal style allowed participants to answer questions without restrictions. The data obtained from the interviews were complemented with information provided by the organization.

\section{Results}

This section describes the evaluation of Bl projects in the organization, focusing on how the evaluation is done, who participates in the process, how the success is measured, as well as the used criteria. These aspects are directly related to the questions underlying the research.

\section{Business Intelligence at Tintas Robbialac, SA}

In many companies, Chief Executive Officers (CEO) are progressively appealing to BI departments to help them in the definition of the company strategy since they can 
contribute significantly to the increase of profitability, productivity and company positioning in the market. In a company with a $\mathrm{Bl}$ department, the access to data analysis is more efficient and accurate than in a company without it (Foster et al., 2015). A BI department typically has access to all the information about the company.

Tintas Robbialac, SA has a BI department, which is assigned to the Commercial area. It interacts with different areas: Marketing, through marketing campaigns and new product releases; Production (logistics), through monthly forecasts and campaigns forecasts; and Financial, through sales and customers forecasts. To compile all the data, it is necessary to have tools and software that allow creating reports or analyses on time. The department uses software from two well-known vendors.

Regarding the Commercial area, BI has goals per customer, salesmen, areas, and channels, divided by type of products (paints), brands and classification of clients, through different commercial metrics (value, volume, margin, etc.). The achievement of these goals is monitored and controlled daily and monthly, allowing the correction of eventual deviations on time.

In the Marketing department, another goal of $\mathrm{Bl}$ is monitoring marketing campaigns and propose commercial promotions. All projects developed by the $\mathrm{Bl}$ team, for example, commercial promotions, are followed along the month, and the participating teams receive the follow-up of these projects. In order to have this information up-to-date, all these campaigns are recorded in the CRM system. This way, it is possible to create analysis reports about campaign results.

Figure 1 shows the interactions of the $\mathrm{Bl}$ department with the other areas of the organization.

Figure 1

Interaction of the BI Department with the Other Business Areas

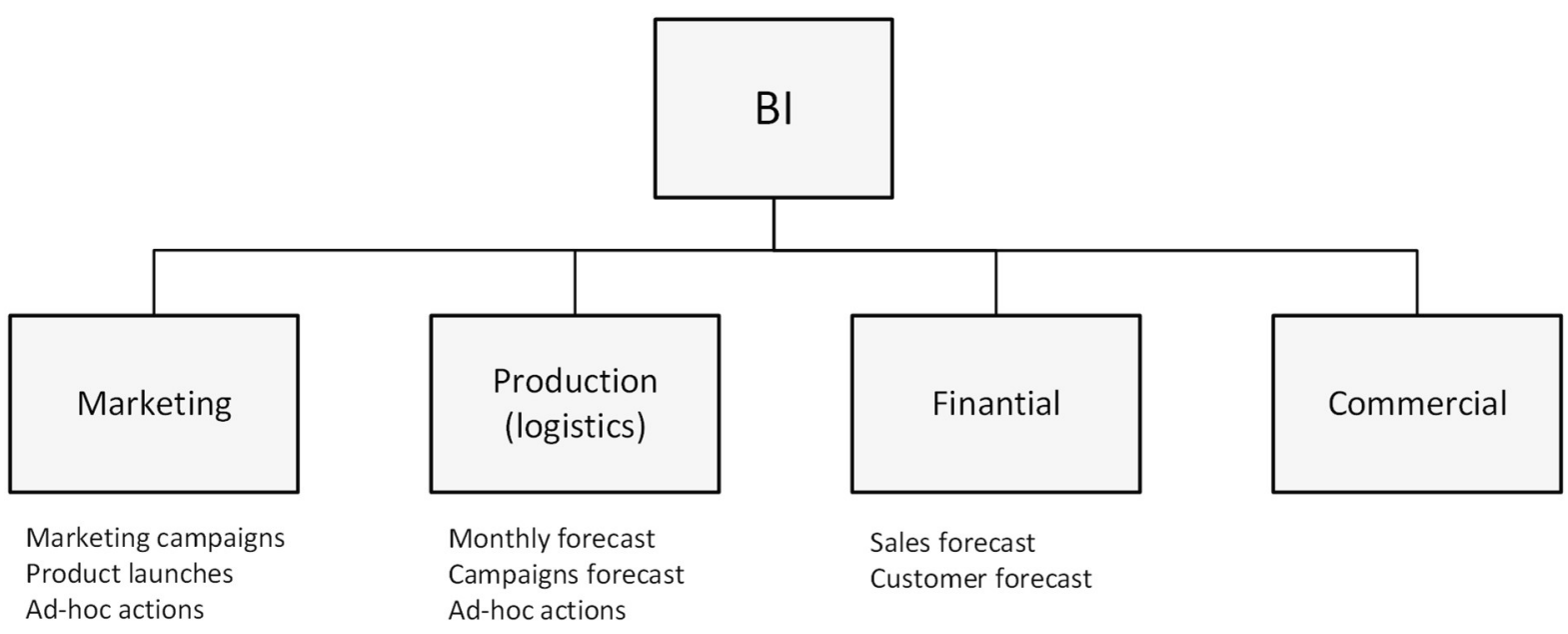

Source: Authors' illustration

\section{Evaluation of BI projects at Tintas Robbialac, SA}

The next sections address the questions: 1) "When the evaluation of BI projects is done and who participates? 2) How success is measured and which are the used criteria?

When the evaluation of $\mathrm{Bl}$ projects is done and who participates?

Regarding the research questions described in section 1, this section aims to get answers for RQ1 and RQ2. 
In Tintas Robbialac SA, the evaluation of BI projects is a continuous process because "the company has continuous changes - new products, new customers" (INT2). Furthermore, the projects are always in a learning cycle and continuous improvement, requiring a continuous evaluation process - "We always try to find new methods, and that is why we are always evaluating" (INT4). In other words, "this process allows improving the projects increasingly" (INT8). Although this process is characterized as continuous, the participants mentioned that it is more focused on monthly and quarterly closings. However, depending on the requirements of the project, the evaluation can happen more times.

The current process allows to implement corrective measures - "each time is done one evaluation to the project, are then implemented measures to correct deviations (if they are found)" (INT4). These actions during the project require more frequent evaluations, so is typically not defined at planning time when the evaluation should be done.

Stakeholders participate in the evaluation process depending on the type of projects. Some projects require the participation of the Executive Committee, and there are others that do not need this participation. In most of the cases, all people involved in the project participate ("All people that receive the information and all people involved in projects should participate in the evaluation" (INT11)).

Figure 2 presents the process of evaluation of BI projects success.

Figure 2

General Process of BI Project Evaluation
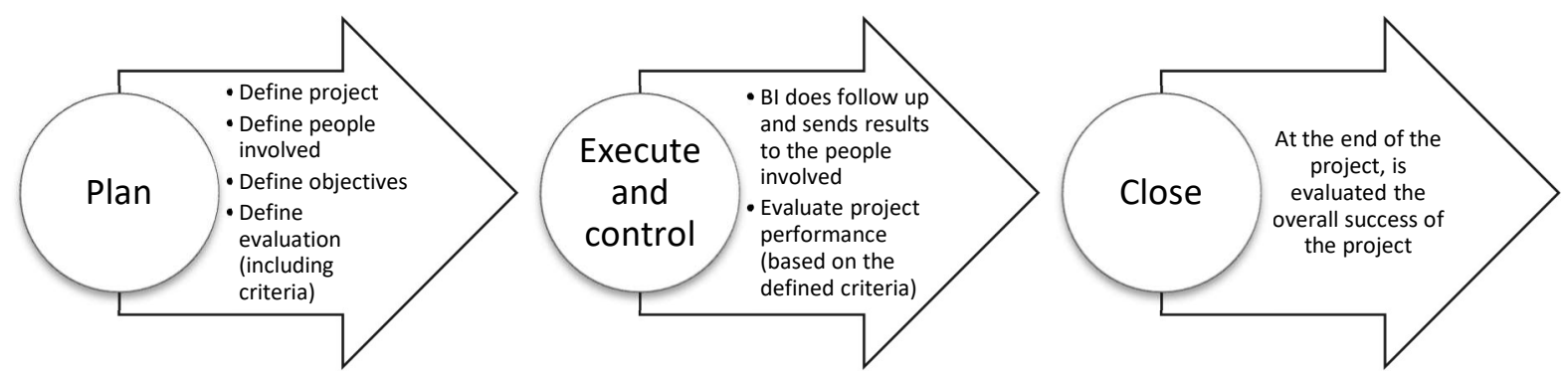

Source: Authors' illustration

How success is measured and which are the used criteria?

This section answers questions RQ3 and RQ4.

The success is measured through three levels: report output level; cooperation level with other areas; and support level (including response time). Besides, "the success of work is inherent to company results" (INT2). The success can be measured through net sales results, growth in "numerical distribution" (the increase of customers) and margin generated (performance and customers profitability). Also, it is measured regarding BI support in decision-making (optimization and standardization of information). "In summary, the success is measured by feedback, performance, adhesion, and skills of people that work in these projects and who receive these data" (INT8).

Some other criteria and techniques are used: adhesion (by use level) from the different teams; qualitative and quantitative results; support at customers visitation (Visitation Plan); control tools; daily follow-up of the projects launched; time, assertiveness and efficiency of the actions; performance, skills, motivation, quality and feedback of people involved. 
Although there is a significant interaction of the people involved in projects, and the $\mathrm{BI}$ team receive feedback from the $\mathrm{BI}$ users, only $45 \%$ of the participants in the interviews find the method used for evaluating the most appropriate. The remaining participants indicate that many times there are no formal criteria defined besides the objectives: at the beginning of the project the objectives are defined, and the evaluation is done only according to these objectives. Everything else is informal, and this can hinder success. Some answers indicate that there should be more regular status meetings.

\section{Discussion}

With the purpose of contributing to a better understanding of the evaluation of $\mathrm{BI}$ projects success, an exploratory case study was carried out in the company Tintas Robbialac, SA. The following subsections discuss some of the most consensual aspects presented by participants.

The importance of an organization having an area dedicated to $\mathrm{Bl}$ All the participants except one in the interviews stated that it is essential for a company to have an organizational area dedicated to BI. The exception was one participant that answered that this importance depends on the dimension of the company. $\mathrm{A} \mathrm{BI}$ department allows to improve the analysis of the business, and the data is structured to support the decision-making. In this way there is more agility and quality in data processing - "the tactical actions carried out to implement the company strategy, are improved by having a Bl department to measure pros and cons, and to evaluate all business metrics" (INT3). In the middle and long-term, the organization has a better vision of all information about the business. Before Titans Robbialac, SA having a BI department, it was difficult to have access to data, because there were no tools or software that allowed to have the information and the data on time - "By that time the actions were not data-driven; nowadays all actions are based on data analysis" (INT1).

\section{The importance of the Bl software quality used by Tintas Robbialac,} SA for the success of projects

All participants in this case study answered that the quality of software and tools used by Robbialac's BI team is fundamental because: the software and tools are according to the dimension of the company and to the reality of its markets; it allows to analyze the needs of organization; and, to do a continuous evaluation/analysis of all business metrics; "it has quick, specific and detailed information" (INT7). In the case of Tintas Robbialac, SA there is a database with data in real time. In other words, "these tools are very important and indispensable to good business performance" (INT1).

\section{The impact of the evaluation of the success of Bl projects}

The evaluation of the success of BI projects has an impact both at the individual as well as at the organizational level.

It has an impact at the individual level because it motivates people involved in the project (the project team and who receives the information), it expresses trust in data, and it helps in decision-making. In other words, "the success of the project is challenging and rewarding; the fact of having recognition at an individual level allows the people to feel integrated into the project" (INT4).

Regarding the organizational level, the Bl area is transversal to the entire company, so all the projects developed by this team can have a profound impact at the 
organizational level and knowing the results of the evaluation enables to improve continuously and raises the confidence levels. These projects help to understand the different channels and the relation among them, as well as, allow understanding the business better and then support the decision-making. In other words, "the success of BI projects contributes to achieving the business goals" (INT5).

\section{Conclusions}

The analysis of the obtained results allows highlighting some important points, which are summarized in Figure 3.

Figure 3

Main conclusions

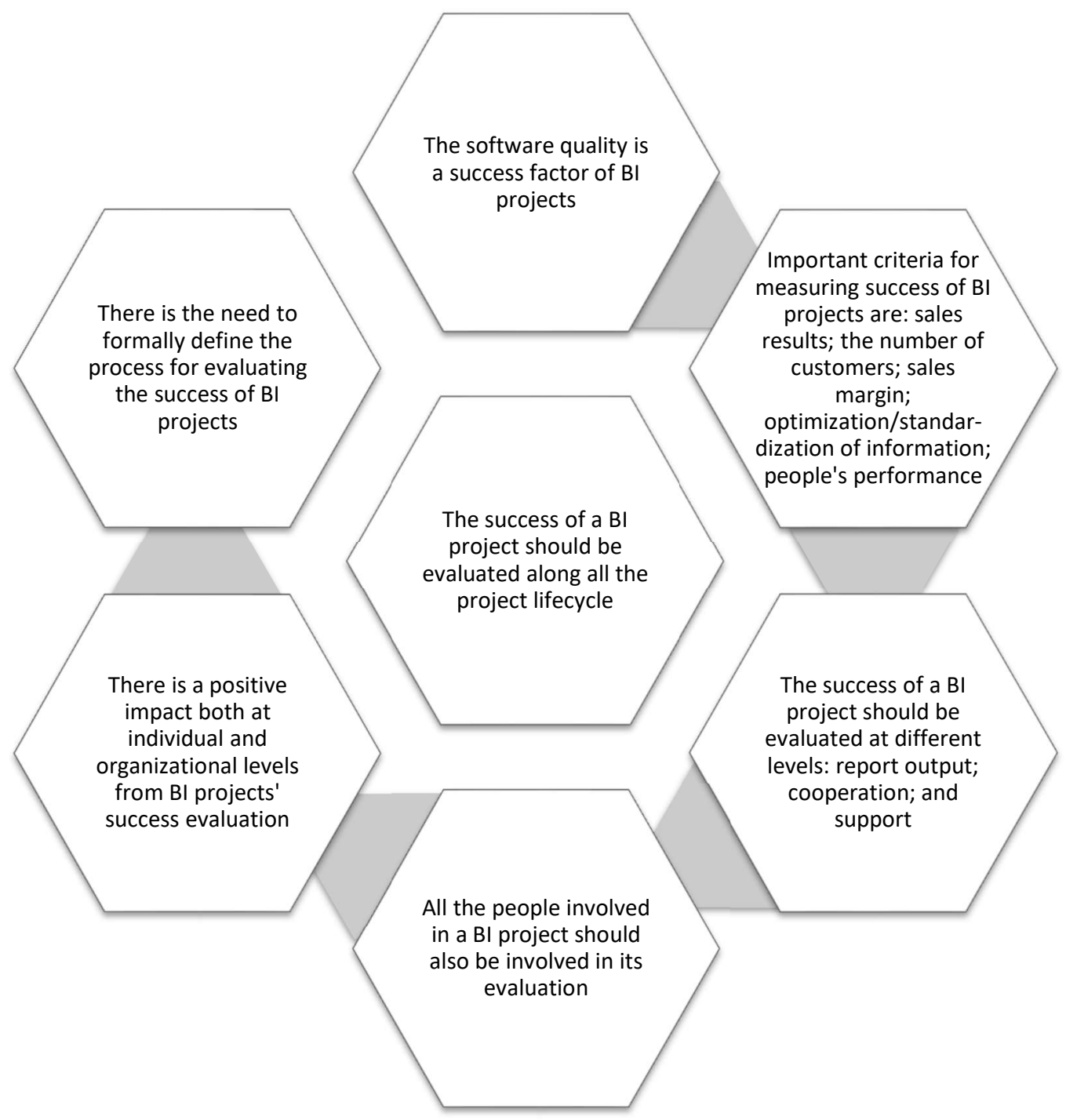

Source: Authors' illustration

The quality of BI software is a relevant success factor. All participants referred that $\mathrm{BI}$ software is fundamental because it allows analyzing business metrics in real time and it allows having data on time. Some important criteria to be used to evaluate the success of a Bl project are sales results, the number of customers, sales margin, optimization and standardization of information, and performance of people that 
work with the data resulting from BI projects. The success of a BI project should be evaluated continuously, in order to be possible to correct deviations on time.

In addition, the success should be evaluated at different levels: report output; cooperation with other areas; and support. All the people involved in a BI project should be directly or indirectly involved in its evaluation. However, there is a positive impact both at individual and organizational levels from evaluating the success of $\mathrm{BI}$ projects. Finally, there is the need to formally define the process for evaluating the success of BI projects and all related aspects (such as the evaluation criteria).

Some of the main conclusions of our study are aligned with the conclusions of the study of Varajão et al. (2016). These authors concluded that the evaluation should be done at different stages of the project, i.e., the evaluation should be done several times during the project and post-project - when this conclusion is compared with the case study of this research, we can state that in Tintas Robbialac, SA happens the same. Similarly, to Tintas Robbialac, SA, they state that the various stakeholders should be involved in the evaluation process of project success. Regarding the evaluation process, they conclude that criteria should be adapted for each project - while in Tintas Robbialac, SA the criteria are defined for each project, however not always in a formal way. Also, they conclude that the information for the evaluation of the project can be obtained from several sources which should be combined to enrich the perception of success - the same is done in Tintas Robbialac, SA.

The main limitation of this research is that it is based on a single case study, i.e., the data was gathered at a single company. Nevertheless, it brings new insights and opens new avenues for research, and new studies should be carried out on the subject aiming at exploring the obtained results.

\section{References}

1. Ardimento, P., Convertini, V. N., Visaggio, G. (2013), "Building a knowledge experience base for facilitating innovation", International Journal of E-Services and Mobile Applications (IJESMA), Vol. 5, No. 4, pp. 40-49.

2. Besteiro, É. N. C., de Souza Pinto, J., Novaski, O. (2015), "Success Factors in Project Management", Business and Management Dynamics, Vol. 4, No. 9, pp. 19-34.

3. Bosilj Vukšić, V., Pejić-Bach, M., Popovič, A. (2013), "Supporting performance management with business process management and business intelligence: $A$ case analysis of integration and orchestration", International journal of information management, Vol. 33, No. 4, pp. 613-619.

4. Chaudhuri, S., Dayal, U., Narasayya, V. (2011), "An overview of business intelligence technology", Communications of the ACM, Vol. 54, No. 8, pp. 88-98.

5. Cheng, J. L. C., McKinley, W. (1983), "Toward an Integration of Organization Research and Practice: A Contingency Study of Bureaucratic Control and Performance in Scientific Settings", Administrative Science Quarterly, Vol. 28, No. 1, pp. 85-100.

6. Collins, A., Baccarini, D. (2004), "Project Success - A survey", Journal of Construction Research, Vol. 5, No. 2, pp. $211-231$.

7. de Carvalho, M. M., Patah, L. A., de Souza Bido, D. (2015), "Project management and its effects on project success: Cross-country and cross-industry comparisons", International Journal of Project Management, Vol. 33, No. 7, pp. 1509-1522.

8. Dobrev, K., Hart, M. (2015), "Benefits, Justification and Implementation Planning of RealTime Business Intelligence Systems", Electronic Journal of Information Systems Evaluation, Vol. 18, No. 2, pp. 104-118.

9. Evans, J. R. (2015), "Modern Analytics and the Future of Quality and Performance Excellence", Quality Management Journal, Vol. 22, No. 4, pp. 6-17.

10. Fourati-Jamoussi, F., Niamba, C. N. (2016), "An evaluation of business intelligence tools: a cluster analysis of users' perceptions", Journal of Intelligence Studies in Business, Vol. 6, No. 1, pp. 37-47. 
11. Foster, K., Smith, G., Ariyachandra, T., Frolick, M. N. (2015), "Business Intelligence Competency Center: Improving Data and Decisions", Information Systems Management, Vol. 32, No. 3, pp. 229-233.

12. Gable, G. G., Sedera, D. Chan, T. (2008), "Re-conceptualizing Information System Success: The IS-Impact Measurement Model", Journal of the Association for Information Systems, Vol. 9, No. 7, pp. 377-408.

13. Gemünden, H. D. (2015), "Success Factors of Global New Product Development Programs, the Definition of Project Success, Knowledge Sharing, and Special Issues of Project Management Journal", Project Management Journal, Vol. 46, No. 1, pp. 2-1 1.

14. Greco, M., Grimaldi, M., Hanandi, M. (2013), "How to select knowledge management systems: a framework to support managers", International Journal of Engineering Business Management, Vol. 5, available at: http://journals.sagepub.com/doi/full/10.5772/56003 (28 May 2018).

15. Grenci, R. (2015), "Incorporating Business Intelligence into Marketing and Managementrelated coursework", Academic of Educational Leadership Journal, Vol. 19, No. 1, pp. $217-$ 226.

16. Ika, L. A. (2009), "Project Success as a Topic in Project Management Journals", Project Management Journal, Vol. 40, No. 4, pp. 6-19.

17. Istrat, V., Starvisavljev, S., Markoski, B., (2015), "The Role of Business Intelligence in Decisionmaking", The European Journal of Applied Economics, Vol. 12, No. 2, pp. 44-52.

18. Ivan, M. L. (2014), "Characteristics of In-Memory Business Intelligence", Informatica Economică Journal, Vol. 18, No. 3, pp. 17-25.

19. Khan, R. A., Quadri, S. M. K. (2012), "Business intelligence: an integrated approach", Business Intelligence Journal, Vol. 5, No. 1, pp. 64-70.

20. Khang, D. B., Moe, T. L. (2008), "Success Criteria and Factors for International Development Projects: A Life-Cycle-Based Framework", Project Management Journal, Vol. 39, No. 1, pp. 72-84.

21. Loebbecke, C., Thomas, B. (2016), "Developing and enforcing internal information systems standards: InduMaker's standards management process", International Journal of Information Systems and Project Management, Vol. 4, No. 1, pp. 5-24.

22. Morio, J. (2014), "Linking Business Intelligence to Strategy", Financial Executive, Vol. 30, No. 4, pp. 66-70.

23. Nenni, M. E., Arnone, V., Boccardelli, P., Napolitano, I. (2014), "How to increase the value of the project management maturity model as a business-oriented framework", International Journal of Engineering Business Management, Vol. 6, No. 8, pp. 1-7.

24. Nyblom, M., Behrami, J., Nikkilä, T., Søilen, K. S. (2012), "An evaluation of Business Intelligence Software systems in SMEs - a case study", Journal of Intelligence Studies in Business, Vol. 2 , No. 2, pp. 51-57.

25. Obeidat, M., North, M., Richardson, R., Rattanak, V., North, S. (2015), "Business Intelligence Technology, Applications, and Trends", International Management Review, Vol. 11, No. 2 , pp. 47-56.

26. Pejić-Bach, M., Zoroja, J., Čeljo, A. (2017), "An extension of the technology acceptance model for business intelligence systems: project management maturity perspective", International Journal of Information Systems and Project Management, Vol. 5, No. 2, pp. 521.

27. Pejić-Bach, M., Jaklič, J., Vugec, D. S. (2018), "Understanding impact of business intelligence to organizational performance using cluster analysis: does culture matter?", International Journal of Information Systems and Project Management, Vol. 6, No. 3, pp. 63-86.

28. Pelegrini, F. G., Jordão, R. V. D., Jeunon, E. E., Jordão, A. C. T. (2015), "Fatores Críticos Na Gestão De Projetos: Um Estudo De Caso Numa Empresa De Grande Porte", Gestão \& Produção, Vol. 22, No. 2, pp. 280-294.

29. Petter, S., DeLone, W., McLean, E. R. (2012), "The Past, Present, and Future "IS Success"'", Journal of the Association for Information Systems, Vol. 13, pp. 341-362.

30. Rechenthin, D. (2013), Project Intelligence, Project Management Institute, Newtown Square, Pennsylvania. 
31. Rusaneanu, A. (2013), "Comparative Analysis of the Main Business Intelligence Solutions", Informatica Economică Journal, Vol. 17, No. 2, pp. 148-156.

32. Schlegelmilch, J., Albanese, J. (2014), "Applying business intelligence innovations to emergency management", Journal of Business Continuity \& Emergency Planning, Vol. 8, No. 1, pp. 31-40.

33. Schlesinger, P. A., Rahman, N. (2015), "Self-Service Business Intelligence Resulting in Disruptive Technology", Journal of Computer Information Systems, Vol. 56, No. 1, pp. 11-21.

34. Serra, C. E. M., Kunc, M. (2015), "Benefits Realization Management and its influence on project success and on the execution of business strategies", International Journal of Project Management, Vol. 33, No. 1, pp. 53-66.

35. Tavallaei, R., Shokohyar, S., Moosvi, S. M., Sarfi, Z. (2015), "Assessing the Evaluation Models of Business Intelligence Maturity and Presenting an Optimized Model", International Journal of Management, Accounting and Economics, Vol. 2, No. 9, pp. 1005-1019.

36. Terzieva, M., Morabito, V. (2016), "Learning from experience: the project team is the key", Business Systems Research Journal, Vol. 7, No. 1, pp. 1-15.

37. Thamir, A., Poulis, E. (2015), "Business Intelligence Capabilities and Implementation Strategies", International Journal of Global Business, Vol. 8, No. 1, pp. 34-35.

38. Teixeira, A., Oliveira, T., Varajão, J. (2018), "Evaluation of Business Intelligence Project Success in Tintas Robbialac: work-in-progress", ENTRENOVA 6-8, September, Croatia.

39. Todorović, M. L., Petrović, D. Č., Mihić, M. M., Obradović, V. L., Bushuyev, S. D. (2015), "Project success analysis framework: A knowledge-based approach in project management", International Journal of Project Management, Vol. 33, No. 4, pp. 772-783.

40. Tomasura, M. (2015), "Business Intelligence Design Using an Interdisciplinary Approach", Business Intelligence Journal, Vol. 20, No. 1, pp. 44-50.

41. Varajão, J. (2016), "Success Management as a PM knowledge area - work-in-progress", Procedia Computer Science, Vol. 100, pp. 1095-1102.

42. Varajão, J. (2018), "A new process for success management - bringing order to a typically ad-hoc area", Journal of Modern Project Management, Vol. 5, No. 3, pp. 94-99.

43. Varajão, J., Magalhães, L., Freitas, L., Ribeiro, P., Ramos, J. (2018), "Implementing Success Management in an IT project", Procedia Computer Science, Vol. 138, pp. 891-898.

44. Varajão, J., Trigo, A. (2016), "Evaluation of IS project success in InfSysMakers: an exploratory case study", in Proceedings of 37th International Conference on Information Systems, Dublin, Ireland, Association for Information Systems, pp. 1-10.

45. Westfall, R. D. (2012), "An Employment-Oriented Definition of the Information Systems Field: An Educator's View", Journal of Information Systems Education, Vol. 23, No. 1, pp. 63-70.

\section{Appendix}

Structure of the interviews (script):

Job: ___ Background: ___ ; Age:

Q1. Please characterize your company before and after having a BI department.

Q2. Do you consider important/relevant for the company to have a BI department? Why?

Q3. How is the evaluation of a BI project done in the company? In your opinion, what is the impact of the BI projects?

Q4. Which are the criteria used for evaluating a project?

Q5. When is the evaluation done? Is it a continuous process?

Q6. Who participates in the evaluation process?

Q7. In your opinion, the method used for the evaluation is the most appropriated one? Why?

Q8. Do you consider the quality of the software/tools used by BI as a relevant factor for projects' success? Why?

Q9. In your opinion, the evaluation of success of BI projects has an impact at individual level? Why?

Q10. And at organizational level? Why? 


\section{About the authors}

Ana Teixeira is graduated in Mathematics Applied to Economics and Management at Lisbon School of Economics \& Management (University of Lisbon). In 2017, she finished her master in Information Management with specialization in Marketing Intelligence at Information Management School (NOVA University). She is currently working as a Market Analyst at Tintas Robbialac, SA (Portugal). The author can be contacted at m2014081@novaims.unl.pt.

Tiago Oliveira is Associate Professor at the NOVA Information Management School (NOVA IMS) and Coordinator of the degree in Information Management. His research interests include technology adoption, digital divide and privacy. He has published papers in several academic journals and conferences, including the Information \& Management, Decision Support Systems, Computers in Human Behavior, Journal of Business Research, Information Systems Frontiers, International Journal of Information Management, Journal of Global Information Management, Industrial Management \& Data Systems, Computers in Industry, among others. Tiago has authored more than 100 scientific articles in Journals and conference proceedings. Tiago has more than 3250 citations. The author can be contacted at toliveira@novaims.unl.pt.

João Varajão is currently professor of information systems and project management at the University of Minho (Portugal). He is also a researcher of the ALGORITMI research center. Born and raised in Portugal, he attended the University of Minho, earning his Graduate (1995), Masters (1997) and Doctorate (2003) degrees in Technologies and Information Systems. In 2012, he received his Habilitation degree from the University of Trás-os-Montes e Alto Douro. His current main research interests are in Information Systems Project Management and Information Systems Management. The author can be contacted at varajao@dsi.uminho.pt. 